\title{
Erosion and sediment budget of the 2008 Wenchuan earthquake: A case study on Mianyuan River basin
}

\author{
Lijian $\mathbf{Q i}^{1^{*}}$, Zhaoyin Wang ${ }^{2}$, Xuzhao Wang $^{3}$ \\ ${ }^{1}$ Department of Hydraulic and Architecture Engineering, Sichuan Agricultural University, Ya'an, China; \\ *Corresponding Author: qilij7@163.com \\ ${ }^{2}$ State Key Laboratory of Hydro-Science and Engineering, Tsinghua University, Beijing, China \\ ${ }^{3}$ Beijing Institute of Geology for Mineral Resources, Beijing, China
}

Received 15 June 2012; revised 17 July 2012; accepted 29 July 2012

\section{ABSTRACT}

The 2008 Wenchuan earthquake of magnitude $\mathbf{6 . 5}$ caused a large number of avalanches and landslides at different scales. It is extremely significant to evaluate the sediment in the earthquake river basins. Along the $\mathbf{3 8} \mathbf{~ k m}$ long upper Mianyuan River 196 landslides and avalanches happened during the earthquake, which have formed 25 landslide dams and quake lakes. The total volume of sediment erosion due to earthquake was about 115 million $\mathrm{m}^{3}$, which is 75 times higher than the soil erosion in normal years. Only a part of the solid material could be transported by the river water flow as suspended load and bed load. The total volume of bed load deposit in the river and the quake lakes was 1.43 million $\mathrm{m}^{3}$. Moreover, the quake lakes had also trapped 0.12 million $\mathrm{m}^{3}$ suspended load. Only 0.18 million $\mathrm{m}^{3}$ of fine sediment had been drifted through the quake lakes and transported into the lower reaches of the Mianyuan River. The wide range of size distributions of sediment from earthquake erosion caused the extreme difference in the amounts of sediment erosion and transportation. Most of the sediment from earthquake erosion can be only transported for a short distance by landslides and debris flows. Less than $0.2 \%$ of the total volume of sediment from earthquake erosion may be transported into large rivers. Therefore, earthquake erosion has a little effect on the sediment transportation and fluvial processes in the large rivers.

Keywords: Erosion; Sediment Budget; Wenchuan Earthquake; Mianyuan River

\section{INTRODUCTION}

Wenchuan Earthquake has led to a lot of secondary mountain disasters such as landslides and avalanches, and the landslides number only is up to more than 5600 [1]. Landslides and avalanches destroyed large quantities of mountains and forest cover, formed large barren area, exacerbate soil erosion. What's more, loose deposits were piled in the valleys and hillsides, and the amount is exceeded $50 \times 10^{8} \mathrm{~m}^{3}[2-5]$.

There are many large rivers in Wenchuan Earthquake area. The secondary mountain disaster is current distribution along the river systems, and most of them are along Minjiang River or nearly perpendicular to Shitingjiang River, Mianyuan River and other deep valleys or branches. On both sides of the valleys, the mountains are mid- and high steep mountains due to strong cutting, and developed large quantities of secondary mountain disasters, such as collapse, landslides and rock fall resulting from earthquake [2,6-8]. Another part of sediment transformed as debris flow into river with rainfall and shaped into barrier lake, which caused big change of the related river. Wenchuan Earthquake has increased soil erosion, stronger erosion intensity and larger leaching out in the disaster area. Therefore, the sediment transport capacity will be varied after earthquake. This paper is objected to discuss earthquake impacts on the sediment transport by means of survey in Mianyuan River.

\section{STUDY REGION AND METHODS}

Mianyuan River is the origin of Tuojiang, which originated from the north of Jiuding Mountain in Deyang and located in the storm center of Lutoushan Mountain. Its latitude and length are about $1000 \sim 3000 \mathrm{~m}$ and 129 $\mathrm{km}$ respectively. The river length in the mountain is 50.1 $\mathrm{km}$, the water collection area is $357.1 \mathrm{~km}^{2}$. The average annual runoff is $4.66 \times 10^{8} \mathrm{~m}^{3}$, perennial flood flow is $400 \sim 600 \mathrm{~m}^{3} / \mathrm{s}$, and the largest flood flow is $3300 \mathrm{~m}^{3} / \mathrm{s}$. The average annual flow in the mountain river outlet is $15.36 \mathrm{~m}^{3} / \mathrm{s}$ [9]. Resulting from the geological tectonic movement, strata in this basin has exposed to varying degrees such as Sinian, Cambrian, Silurian, Devonian, 
Carboniferous, Permian, Trias, Jurassic and Quaternary.

Data acquisition is mainly via field measurement. The geometric characteristics of sediment deposit are obtained by the theodolite and laser distance meter. The coordinate position of landmark is decided by high precision GPS receiver, which measurement error is less than $1 \mathrm{~m}$. The total amount is calculated according to the map of 1:50,000 topographic map in 1954 and part of regional post-earthquake map. Basic hydrology measurement is measured by pitot tube, bed load sediment transport rate by slot pit measuring method, suspended load by measuring water sampling.

The seismic secondary disasters in Mianyuan River were surveyed in 2008-2010. The investigation scope was from the downstream of Zhongyanjing to Hanwang, the length and altitude difference of which are about 38 $\mathrm{km}$ and $1052 \mathrm{~m}$ respectively. The mountainous area of Mianyuan River is divided into two parts according to the inlets slope. The first part is from the beginning to Famuchang, the length is $15 \mathrm{~km}$ and slope is $56.9 \%$; the second part is from Famuchang to Hanwang, the slope is $12.5 \%$. While according to the lithology, the mountainous area can be divided into three parts: The firsts part is from the starting point to the loess pit river, the major of lithology is limestone; the second part is from loess pit river to Famuchang, and granite is the main lithology; the last part is from Famuchang to Hanwang, the major of lithology is also limestone. There are many branch valleys in Mianyuan River. Prior to the earthquake, most of the valleys were full of water throughout year, while the water flowing into the branches is only one third after earthquake.

\section{ON-THE-SPOT INVESTIGATION}

\subsection{Earthquake Erosion}

The river valley of Mianyuan river is deeply incised, narrow winding and steep hills on both sides. Most of the collapse and landslides directly flowed into branch valley and main stream. The secondary disaster in Mianyuan river Basin is collapse major in the numbers, but the scale is small. Landslides have large volume but several amount in this area. The Wenjiagou landslide is the second largest landslides in Wenchuan Earthquake Area. The collapses and landslides have developed 22 barrier lake, and 4 of them are considered as the focusing landslides after the earthquake such as Yujunmen landslide in the downstream of Famuchang. Another 5 more barrier lakes were formed after the earthquake because of debris flow. The barrier lake in the downstream of Xiaogangjian has been completely buried by the sands and landslides from the upstream. The barrier lake in Yongjiagou has been eliminated and there are still 25 existing barrier lakes in this area, which are shown in Figure 1.

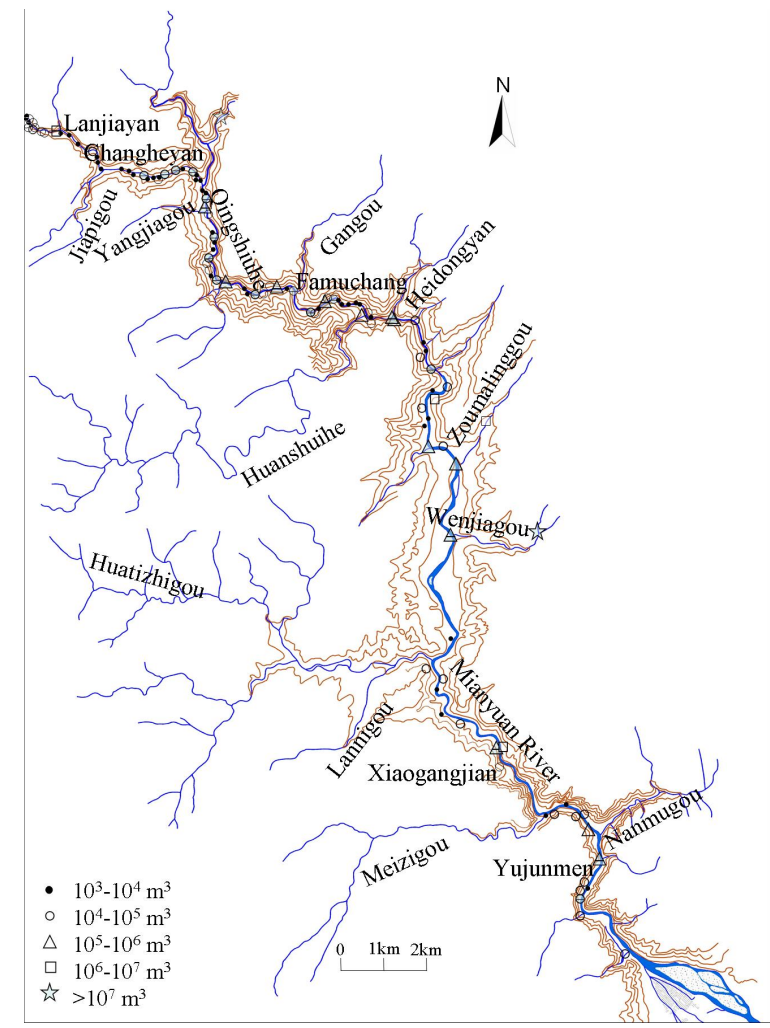

Figure 1. Distribution of avalances, landslides and debris flows in Mianyuan River after the Wenchuan Earthquake.

The sediment volumes above $1000 \mathrm{~m}^{3}$ are measuredand surveyed in this study area. Figure 2 shows that although there are only 2 accumulation body which is above $10 \times 10^{6} \mathrm{~m}^{3}$ in Wenjiagou and Donghe, the whole volume is more than $90 \times 10^{6} \mathrm{~m}^{3}$. The number of the volume about $1 \sim 10 \times 10^{6} \mathrm{~m}^{3}$ is 19 , the total volume is more than $13 \times 10^{6} \mathrm{~m}^{3}$. The number of the sediment body at the range of 1000 to $10,000 \mathrm{~m}^{3}$ is 113 , but the total volume is only $0.23 \times 10^{6} \mathrm{~m}^{3}$. The relationship between the range and number of sediment body is exponential distribution. According to Figure 1 and Table 1, the collapse landslides in the upstream of Famuchang are distributed intensive, especially the small landslides below $1000 \mathrm{~m}^{3}$; but the landslides of downstream in Famuchang are distributed sparsely but the single volume is generally larger than that in the upstream.

There are 196 landslides and debris sediment above $1000 \mathrm{~m}^{3}$ in Mianyuanhe and the whole volume are 114.6 $\times 10^{6} \mathrm{~m}^{3}$ (Figures 3 and 4). The collapse accumulations less than $1000 \mathrm{~m}^{3}$ are not considered in this survey. Actually the sediment yield by earthquake is a little more than the statistical results, but the rate is extremely small compared with the total amount of erosion.

\subsection{Sediment from Short Distance}

Some of the sediments in Mianyuanhe main stream are 


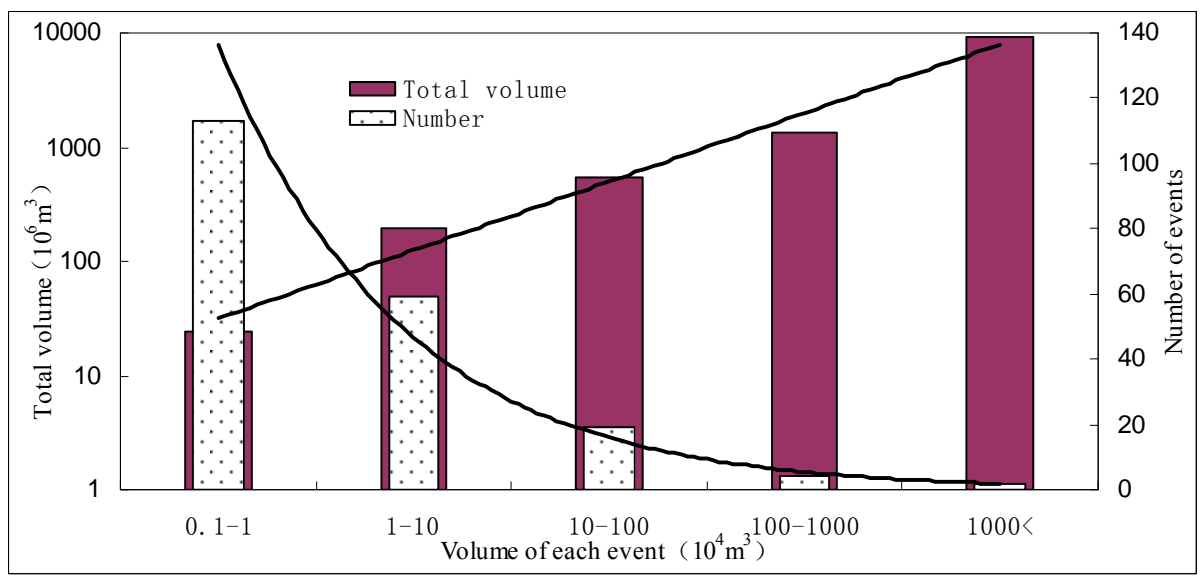

Figure 2. Distribution of the main collapse in Mianyuan River.

Table 1. Statistics of the main accumulated body.

\begin{tabular}{|c|c|c|c|c|c|}
\hline Site & \multicolumn{2}{|c|}{ Location (GPS) } & Volume $\left(10^{4} \mathrm{~m}^{3}\right)$ & $\mathrm{D}_{50}(\mathrm{~mm})$ & Type of Disaster \\
\hline Upstream of Yixiantian (tributary) & $31^{\circ} 37^{\prime} 13.6^{\prime \prime} \mathrm{N}$ & $104^{\circ} 01^{\prime} 13.8^{\prime \prime} \mathrm{N}$ & 10 & 650 & Collapse \\
\hline Outlet of Yixiantian & $31^{\circ} 37^{\prime} 37.9^{\prime \prime} \mathrm{N}$ & $104^{\circ} 01^{\prime} 26.8^{\prime \prime} \mathrm{N}$ & 16 & 20 & Collapse \\
\hline Lanjiayan & $31^{\circ} 38^{\prime} 00.3^{\prime \prime} \mathrm{N}$ & $104^{\circ} 01^{\prime} 22.4^{\prime \prime} \mathrm{N}$ & 147 & 3000 & Landslide \\
\hline Donghe (tributary) & $31^{\circ} 38^{\prime} 25.6^{\prime \prime} \mathrm{N}$ & $104^{\circ} 03^{\prime} 24.0^{\prime \prime} \mathrm{N}$ & 1217 & 1500 & Collapse \\
\hline Yangjiagou & $31^{\circ} 37^{\prime} 22.1^{\prime \prime} \mathrm{N}$ & $104^{\circ} 03^{\prime} 03.1^{\prime \prime} \mathrm{N}$ & 28 & 300 & Debris flow \\
\hline Upstream reaches of Gangou & $31^{\circ} 36^{\prime} 16.1^{\prime \prime} \mathrm{N}$ & $104^{\circ} 04^{\prime} 14.8^{\prime \prime} \mathrm{N}$ & 48 & 1000 & Collapse \\
\hline Outlet of Huangshuigou (tributary) & $31^{\circ} 35^{\prime} 56.5^{\prime \prime} \mathrm{N}$ & $104^{\circ} 05^{\prime} 35.3^{\prime \prime} \mathrm{N}$ & 21 & 2600 & Collapse \\
\hline Upstream reaches of Heidongyan & $31^{\circ} 35^{\prime} 56.7^{\prime \prime} \mathrm{N}$ & $104^{\circ} 06^{\prime} 00.5^{\prime \prime} \mathrm{N}$ & 30 & 20 & Debris flow \\
\hline Heidongyan & $31^{\circ} 35^{\prime} 52.7^{\prime \prime} \mathrm{N}$ & $104^{\circ} 06^{\prime} 04.4^{\prime \prime} \mathrm{N}$ & 42 & 610 & Collapse \\
\hline Zhayaoku & $31^{\circ} 35^{\prime} 52.8^{\prime \prime} \mathrm{N}$ & $104^{\circ} 06^{\prime} 16.5^{\prime \prime} \mathrm{N}$ & 10 & 45 & Debris flow \\
\hline Xiangshuigou & $31^{\circ} 35^{\prime} 01.6^{\prime \prime} \mathrm{N}$ & $104^{\circ} 06^{\prime} 43.1^{\prime \prime} \mathrm{N}$ & 175 & 20 & Collapse \\
\hline Yongjiagou & $31^{\circ} 34^{\prime} 19.5^{\prime \prime} \mathrm{N}$ & $104^{\circ} 06^{\prime} 25.2^{\prime \prime} \mathrm{N}$ & 14 & 10 & Debris flow \\
\hline Zoumaling & $31^{\circ} 34^{\prime} 03.4^{\prime \prime} \mathrm{N}$ & $104^{\circ} 06^{\prime} 57.5^{\prime \prime} \mathrm{N}$ & 25 & 170 & Debris flow \\
\hline Wenjiagou (tributary) & $31^{\circ} 32^{\prime} 57.5^{\prime \prime} \mathrm{N}$ & $104^{\circ} 07^{\prime} 56.7^{\prime \prime} \mathrm{N}$ & 8160 & 120 & Landslide \\
\hline Wenjiagou & $31^{\circ} 33^{\prime} 07.4^{\prime \prime} \mathrm{N}$ & $104^{\circ} 06^{\prime} 54.0^{\prime \prime} \mathrm{N}$ & 90 & 110 & Debris flow \\
\hline Xiaogangjian Barrier Dam & $31^{\circ} 30^{\prime} 15.7^{\prime \prime} \mathrm{N}$ & $104^{\circ} 07^{\prime} 37.4^{\prime \prime} \mathrm{N}$ & 48 & 140 & Collapse \\
\hline Left collapse in Xiaogangjian & $31^{\circ} 30^{\prime} 15.7^{\prime \prime} \mathrm{N}$ & $104^{\circ} 07^{\prime} 37.4^{\prime \prime} \mathrm{N}$ & 200 & 30 & Collapse \\
\hline Xiaotianchi & $31^{\circ} 29^{\prime} 15.4^{\prime \prime} \mathrm{N}$ & $104^{\circ} 07^{\prime} 50.3^{\prime \prime} \mathrm{N}$ & 800 & 35 & Landslide \\
\hline Upstream collapse group in Yujunmen & $31^{\circ} 29^{\prime} 28.6^{\prime \prime} \mathrm{N}$ & $104^{\circ} 08^{\prime} 52.6^{\prime \prime} \mathrm{N}$ & 18 & 20 & Collapse \\
\hline Yujun Men Barrier Dam & $31^{\circ} 28^{\prime} 56.8^{\prime \prime} \mathrm{N}$ & $104^{\circ} 09^{\prime} 05.6^{\prime \prime} \mathrm{N}$ & 25 & 700 & Collapse \\
\hline
\end{tabular}

carried by the collapse when earthquake happened; others are coming by the debris flow from the branch valleys. The total volume of sediments in Mianyuanhe is $10.42 \times 10^{6} \mathrm{~m}^{3}$ at present.

The loose sediments are keeping in the branch valleys. The particles caused by collapse are big, which can be transported to main stream in the form of debris flow with rainstorms and then the barrier lakes are shaped. The downstream of Famuchang is the main distribution area of the debris flow and also the main source flowing into the river. The debris flow frequency is too high. If the daily rainfall depth is more than $20 \mathrm{~mm}$, there will be 


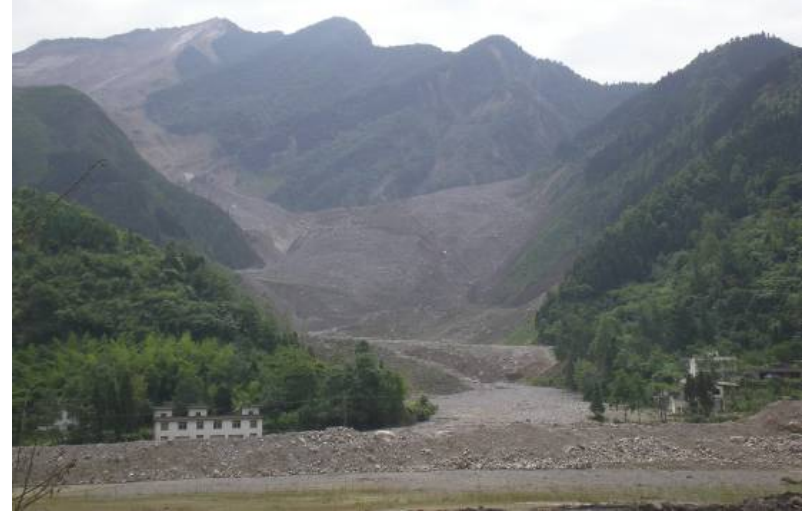

Figure 3. Wenjiagou landslide.

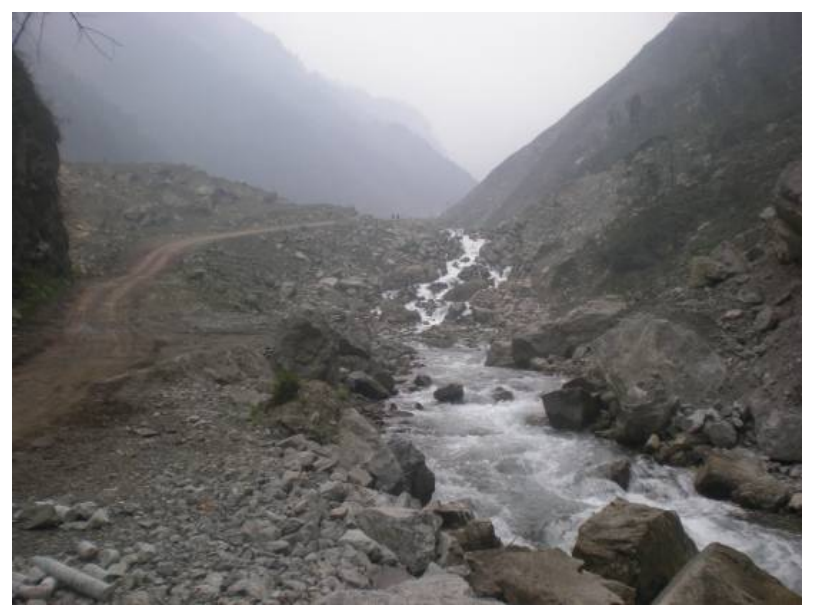

Figure 4. Yangjiagou barrier dam.

some debris flow entering the river. The volume of debris flow into Mianyuanhe is about $5.31 \times 10^{6} \mathrm{~m}^{3}$ in $2008-$ 2010. The main source of debris flow is from Wenjiagou, Yongjiagou, Heidongyan, Zoumaling, which is shown in Figure 5. The debris flow in Wenjiagou has been improved and that in Zoumaling is under programming. The sediment in the main stream of Mianyuanhe will increase in the next 5 - 10 years while the increase rate will be decreased conspicuously. In addition, the slope sediments are piled on both sides of the river, so the debris flow will go into the river on a small scale.

The movement of bed load is violet in the flood season and there is conspicuous change in some rivers, presented in Figure 6. The node of the range of motion of the bed load is barrier lake, which moves between two lakes and silted at the end of the lake. As the channel of the upstream is shallow and deep, the silting between the collapse and bed load make the riverbed raised obviously. The riverbed adjacent to Famuchang has risen about more than $10 \mathrm{~m}$. There is close relation between the river silting degree, both barrier lakes and the size of the col-

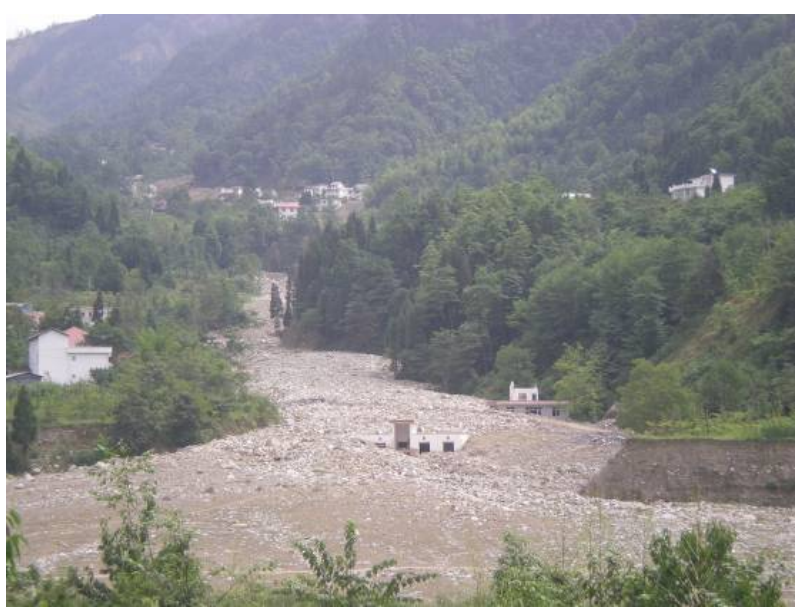

Figure 5. Debris flow in Zoumaling.

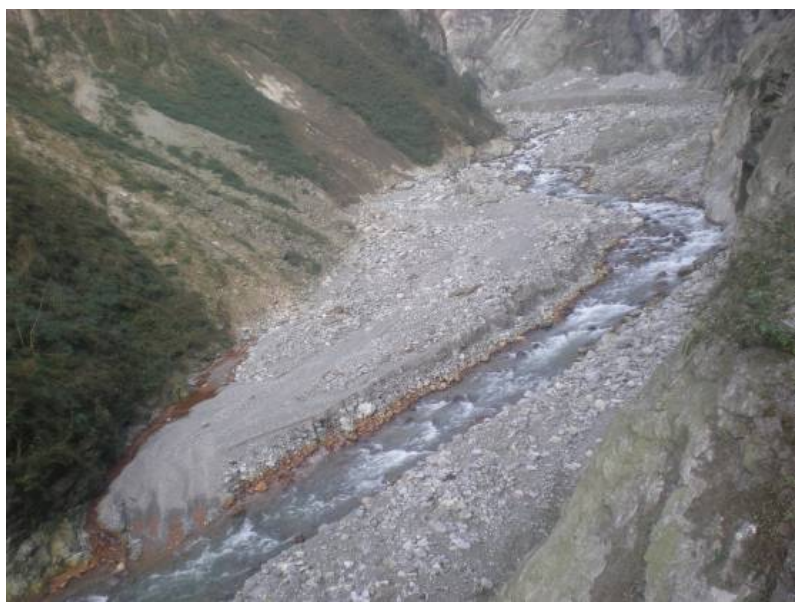

Figure 6. The fierce scouring and silting changes in Zhayaoku.

lapse sediment in the corresponding branch valleys. The total volume of the bed load is about $1.44 \times 10^{6} \mathrm{~m}^{3}$, estimated in Table 2.

The suspended load can be transported from the upstream or branch valley, through barrier dam to the downstream, such as silt and clay. While, some of barrier dams blocked the river and slow down the water speed, which of the sediments can be flowed into Tuojiang or Yangtze River but only silted in the barrier lake. The currents from the upstream of Lanjiayan Barrier lake can be released through seepage. There are small sediments in the control catchment so nearly no sediments were transported to the downstream. The silting depth is thin in the barrier lake and the total sediment yield is few as well. There is big difference in the silting depths of suspended load in the downstream of 22 barrier lake, shown in Table 3. The silty sediment are cumulated in some of the barrier lakes, for example the depth is more than $1 \mathrm{~m}$ in Xiaogangjian Barrier lakes. However there are very little silts in some barrier lakes, such as those in Yaneryangou due to the small storage capacity and no distinct 
Table 2. Statistics of deposition section in the river channel.

\begin{tabular}{|c|c|c|c|c|c|c|}
\hline \multirow{2}{*}{$\begin{array}{c}\text { Site } \\
\text { Lanjiayan barrier lake }\end{array}$} & \multicolumn{2}{|c|}{ Starting point (GPS) } & \multicolumn{2}{|c|}{ Ending point (GPS) } & \multirow{2}{*}{$\frac{\text { Volume }\left(10^{4} \mathrm{~m}^{3}\right)}{4.5}$} & \multirow{2}{*}{$\frac{\mathrm{D}_{50}(\mathrm{~mm})}{30}$} \\
\hline & $31^{\circ} 38^{\prime} 21.4^{\prime \prime} \mathrm{N}$ & $103^{\circ} 59^{\prime} 54.8^{\prime \prime} \mathrm{N}$ & $31^{\circ} 38^{\prime} 35.1^{\prime \prime} \mathrm{N}$ & $104^{\circ} 00^{\prime} 18.2^{\prime \prime} \mathrm{N}$ & & \\
\hline Downstream of Lanjiayan & $31^{\circ} 38^{\prime} 04.3^{\prime \prime} \mathrm{N}$ & $104^{\circ} 01^{\prime} 15.2^{\prime \prime} \mathrm{N}$ & $31^{\circ} 38^{\prime} 00.9^{\prime \prime} \mathrm{N}$ & $104^{\circ} 01^{\prime} 23.4^{\prime \prime} \mathrm{N}$ & 1.5 & 45 \\
\hline Downstream of Yangjiagou & $31^{\circ} 36^{\prime} 57.9^{\prime \prime} \mathrm{N}$ & $104^{\circ} 03^{\prime} 20.1^{\prime \prime} \mathrm{N}$ & $31^{\circ} 36^{\prime} 52.6^{\prime \prime} \mathrm{N}$ & $104^{\circ} 03^{\prime} 21.5^{\prime \prime} \mathrm{N}$ & 2.4 & 25 \\
\hline Maniaoshuibarrier lake & $31^{\circ} 36^{\prime} 45.0^{\prime \prime} \mathrm{N}$ & $104^{\circ} 03^{\prime} 21.3^{\prime \prime} \mathrm{N}$ & $31^{\circ} 36^{\prime} 42.8^{\prime \prime} \mathrm{N}$ & $104^{\circ} 03^{\prime} 19.9^{\prime \prime} \mathrm{N}$ & 1.4 & 50 \\
\hline Yaneryangou barrier lake & $31^{\circ} 36^{\prime} 21.3^{\prime \prime} \mathrm{N}$ & $104^{\circ} 03^{\prime} 27.7^{\prime \prime} \mathrm{N}$ & $31^{\circ} 36^{\prime} 18.7^{\prime \prime} \mathrm{N}$ & $104^{\circ} 03^{\prime} 29.6^{\prime \prime} \mathrm{N}$ & 2.9 & 30 \\
\hline Downstream of Yaneryangou & $31^{\circ} 36^{\prime} 18.8^{\prime \prime} \mathrm{N}$ & $104^{\circ} 03^{\prime} 30.7^{\prime \prime} \mathrm{N}$ & $31^{\circ} 36^{\prime} 18.9^{\prime \prime} \mathrm{N}$ & $104^{\circ} 03^{\prime} 41.9^{\prime \prime} \mathrm{N}$ & 1.8 & 50 \\
\hline Upstream reaches of Gangou & $31^{\circ} 36^{\prime} 11.1^{\prime \prime} \mathrm{N}$ & $104^{\circ} 03^{\prime} 53.7^{\prime \prime} \mathrm{N}$ & $31^{\circ} 36^{\prime} 12.2^{\prime \prime} \mathrm{N}$ & $104^{\circ} 03^{\prime} 58.5^{\prime \prime} \mathrm{N}$ & 1.9 & 10 \\
\hline Gangou Mine & $31^{\circ} 36^{\prime} 10.9^{\prime \prime} \mathrm{N}$ & $104^{\circ} 04^{\prime} 28.5^{\prime \prime} \mathrm{N}$ & $31^{\circ} 36^{\prime} 04.1^{\prime \prime} \mathrm{N}$ & $104^{\circ} 05^{\prime} 29.0^{\prime \prime} \mathrm{N}$ & 1.7 & 10 \\
\hline Qingwashi to Famuchang & $31^{\circ} 36^{\prime} 07.8^{\prime \prime} \mathrm{N}$ & $104^{\circ} 05^{\prime} 08.8^{\prime \prime} \mathrm{N}$ & $31^{\circ} 36^{\prime} 02.4^{\prime \prime} \mathrm{N}$ & $104^{\circ} 05^{\prime} 32.2^{\prime \prime} \mathrm{N}$ & 13.8 & 150 \\
\hline Heidongyan barrier lake & $31^{\circ} 35^{\prime} 56.5^{\prime \prime} \mathrm{N}$ & $104^{\circ} 05^{\prime} 35.3^{\prime \prime} \mathrm{N}$ & $31^{\circ} 36^{\prime} 01.1^{\prime \prime} \mathrm{N}$ & $104^{\circ} 05^{\prime} 31.4^{\prime \prime} \mathrm{N}$ & 2.3 & 12 \\
\hline Downstream of Zhayaoku & $31^{\circ} 35^{\prime} 52.8^{\prime \prime} \mathrm{N}$ & $104^{\circ} 06^{\prime} 16.5^{\prime \prime} \mathrm{N}$ & $31^{\circ} 35^{\prime} 26.7^{\prime \prime} \mathrm{N}$ & $104^{\circ} 06^{\prime} 22.9^{\prime \prime} \mathrm{N}$ & 19.1 & 200 \\
\hline Xiaomuling II hydroplant & $31^{\circ} 34^{\prime} 29.9^{\prime \prime} \mathrm{N}$ & $104^{\circ} 06^{\prime} 26.8^{\prime \prime} \mathrm{N}$ & $31^{\circ} 30^{\prime} 36.3^{\prime \prime} \mathrm{N}$ & $104^{\circ} 07^{\prime} 16.5^{\prime \prime} \mathrm{N}$ & 1.2 & 10 \\
\hline Xiaogangjian barrier lake & $31^{\circ} 30^{\prime} 52.6^{\prime \prime} \mathrm{N}$ & $104^{\circ} 06^{\prime} 47.6^{\prime \prime} \mathrm{N}$ & $31^{\circ} 30^{\prime} 36.3^{\prime \prime} \mathrm{N}$ & $104^{\circ} 07^{\prime} 16.5^{\prime \prime} \mathrm{N}$ & 65.0 & 5 \\
\hline Downstream of Xiaogangjian & $31^{\circ} 30^{\prime} 15.5^{\prime \prime} \mathrm{N}$ & $104^{\circ} 07^{\prime} 38.7^{\prime \prime} \mathrm{N}$ & $31^{\circ} 30^{\prime} 14.0^{\prime \prime} \mathrm{N}$ & $104^{\circ} 07^{\prime} 41.4^{\prime \prime} \mathrm{N}$ & 10.5 & 120 \\
\hline Downstream of Yujunmen & $31^{\circ} 28^{\prime} 56.5^{\prime \prime} \mathrm{N}$ & $104^{\circ} 09^{\prime} 08.1^{\prime \prime} \mathrm{N}$ & $31^{\circ} 28^{\prime} 34.9^{\prime \prime} \mathrm{N}$ & $104^{\circ} 08^{\prime} 51.9^{\prime \prime} \mathrm{N}$ & 9.5 & 210 \\
\hline
\end{tabular}

Table 3. Statistics of sediment deposition in different barrier lakes.

\begin{tabular}{|c|c|c|c|c|c|}
\hline Barrier Lake & $\begin{array}{l}\text { Average thickness } \\
(\mathrm{cm})\end{array}$ & $\begin{array}{c}\text { Sediment deposition } \\
\left(10^{4} \mathrm{~m}^{3}\right)\end{array}$ & Barrier Lake & $\begin{array}{l}\text { Average thickness } \\
(\mathrm{cm})\end{array}$ & $\begin{array}{c}\text { Sediment deposition } \\
\left(10^{4} \mathrm{~m}^{3}\right)\end{array}$ \\
\hline M1 & 15.7 & 0.02 & Ergangqiao & 14.0 & 0.12 \\
\hline M2 & 2.9 & 0.00 & Upstream of Gangou & 0.8 & 0.01 \\
\hline Lanjiayan & 7.6 & 0.73 & Gangou & 8.0 & 0.04 \\
\hline Changheba & 30.8 & 0.09 & Gangou Mine & 9.0 & 0.09 \\
\hline Changheba I & 1.5 & 0.00 & $\begin{array}{l}\text { Downstream of } \\
\text { Gangou Mine }\end{array}$ & 3.0 & 0.05 \\
\hline Changheba II & 4.0 & 0.01 & Qingwashi & 2.6 & 0.03 \\
\hline Damingshan & 10.0 & 0.10 & Heidongyan & 31.3 & 0.94 \\
\hline Yangjiagou & 14.6 & 0.43 & Taohuaping & 12.8 & 0.03 \\
\hline Dishuiyan & 2.3 & 0.01 & Wenjiagou & 22.7 & 0.32 \\
\hline Maniaoshui & 0.1 & 0.00 & Xiaogangjian & 61.7 & 8.16 \\
\hline Yaneryangou & 0.1 & 0.00 & Yujunmen & 22.8 & 0.85 \\
\hline Downstream of Yaneryangou & 0.1 & 0.00 & $\begin{array}{l}\text { Upstream of } \\
\text { Guanyinyan }\end{array}$ & 37.0 & 0.21 \\
\hline
\end{tabular}

slow speed. The silting depth in the downstream of the beaded barrier lakes are thickest, such as the depths of three beaded lakes in downstream of Changheba are 1.5, $4.0,10.0 \mathrm{~cm}$. The silting depths are more than $30 \mathrm{~cm}$ in Xiaogangjian (Figure 7), Yujunmen, and Heidongyan, which is caused by the slow flow speed and weak sediment-carrying capacity, especially the suspended load can be up to thousands of cubic meter. Since the lithol- ogy in the barrier lakes of upstream of Damingshan and downstream of Heidongyan is limestone reaches, the silting depth is much thicker than the granite reaches and is related with the fine particles content of collapse. The movement of suspend load is regional and affected by the barrier lake. The silting depth is smaller in the granite reaches, which also predicted that no more suspended load from limestone piled in this section. The silt and 


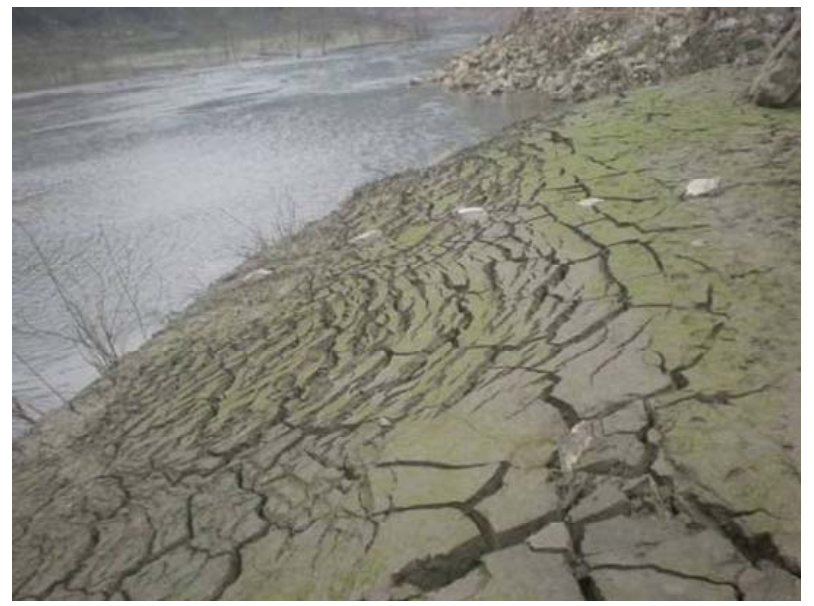

Figure 7. Silt measurement in the Xiaogangiian Barrier lake.

sediments are mainly from the regional branches such as in the barrier lake from Xiaogangjian and Yujunmen. According to the survey, if the suspended load is defined by the diameter below $1 \mathrm{~mm}$ in the barrier lakes, then the total volume is about $12.3 \times 10^{4} \mathrm{~m}^{3}$.

The movement distance is in the scale of several kilometers between the debris flow and bed load, while that of the suspended load is limited as it is constricted by the barrier lake. The volume of short distance transport sediments is about $367.3 \times 10^{4} \mathrm{~m}^{3}$.

\subsection{Wash Load Transport}

There is clear water in Mianyuanhe except muddy in some parts of the whole river for a few days after storm. The sediment flowing into large river mainly is wash load. The average sand content is $0.381 \mathrm{~kg} / \mathrm{m}^{3}$ measured from the water samplings in the outlet of Mianyuan river in the typical month. As there is shortage of sediment transport data, the following analysis is compared with the data from the downstream of Mianyuan river to Tuojiang [10]. The sediment transport amount in the mountain outlet of Mianyuanhe is about $17.8 \times 10^{4} \mathrm{t}$ after earthquake according to the mean annual runoff obtained before earthquake (Ying et al., 1999). The sediment module is $540 \mathrm{t} / \mathrm{km}^{2} \cdot \mathrm{a}$ in Tuojiang Basin before earthquake. Based on this, the annual sediment yield is about $19.2 \times 10^{4} \mathrm{t}$ before earthquake, which is no big difference from that after earthquake.

\section{DISCUSSIONS}

The vegetation coverage is very high before Wenchuan Earthquake in Mianyuanhe Basin. Since the river basin is located in the Longmenshan fault, which is contiguous areas between the west of Sichuan and the east of Qinghai-Tibet Plateau, the complicated geological structure has great impacts on the transformation of surface rock and soil. Annual rainfall can cause few collapse in the small scale during the flood season, but no debris flow occurred. The major erosion type is planar erosion, and the sand particle is finer developed before earthquake.

The annual amount of soil erosion in Mianyuan river before earthquake is about $222 \times 10^{4} \mathrm{t}$, namely $111 \times 10^{4}$ $\mathrm{m}^{3}$, so the erosion and sediment yield after earthquake is equivalent to that gained in 75 years under normal condition.The stone particles are oversize, size disparity and wide grading. Table 1 and Figure 8(a) show that the median particle diameter of the collapse sediment is at the range of $200 \sim 3000 \mathrm{~mm}$. The particle of debris flow is a little smaller and coarse than that of the sediment. The biggest diameter is more than $4 \mathrm{~m}$, and the median one is between $70 \sim 700 \mathrm{~mm}$ shown in Figure 8(b), which is larger than that under the natural erosion in the small basin. Figure 8(c) present that the median diameter of the bed load in the river is much smaller than them, which is at the range of $4 \sim 30 \mathrm{~mm}$. As the barrier lake can slow the water flow speed, there is a substantial quantity of the fine particles $(\mathrm{d}<0.1 \mathrm{~mm})$ in the barrier lake as shown in Figure 9.

The wash load flowing into the downstream of Mianyuanhe is a small amount at present. After analyzing water samples with sand, the annual sediment yield after earthquake is about $17.8 \times 10^{4} \mathrm{t}$, and only occupied $0.08 \%$ compared with the whole volume about $114.6 \times$ $10^{6} \mathrm{~m}^{3}$. The reason is that the collapse-slide accumulation can fill the river bed, and transform the shallow and deep channel to broad one. Although the large amount of sediments flow into the river channel, it is difficult for the suspended particles to be carried with water, so the riverbed will be becoming thick and the riverbed resistance increases. The existing barrier lakes make the capacity larger, which can prevent more sand from transporting. The barrier dams can shape large knickpoints, which can make the identical steep slope steep-slow interphase. Then the river resistance can be increased and the average flow speed decrease, which reduce the sediment carrying capacity.

The total erosion volume is composed of $9.1 \%$ of debris flow and the erosion adjacent to the river, $1.36 \%$ of the short distance transported erosion such as bed load, and $0.08 \%$ of wash load. From the erosion and sediment to debris flow and riverfront erosion, then the bed load and the wash load, there is only one order of magnitude difference from one to another. Therefore, the sand flowing into the downstream is a very small part of the total erosion volume. Consequently, most of the erosion and sediment from Wenchuan earthquake can only be transported at a short distance in the erosion area.

\section{CONCLUSIONS}

Earthquakes cause extremely high rates of sediment 


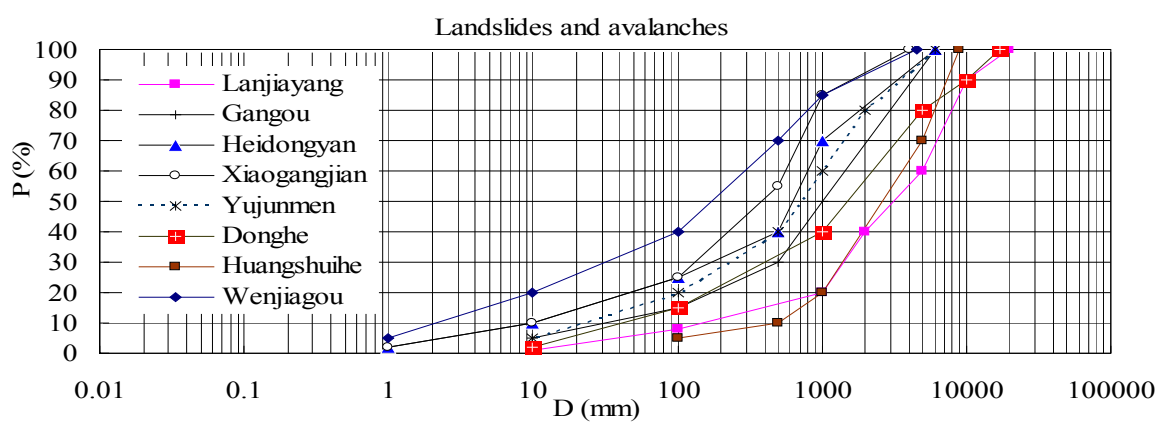

(a)

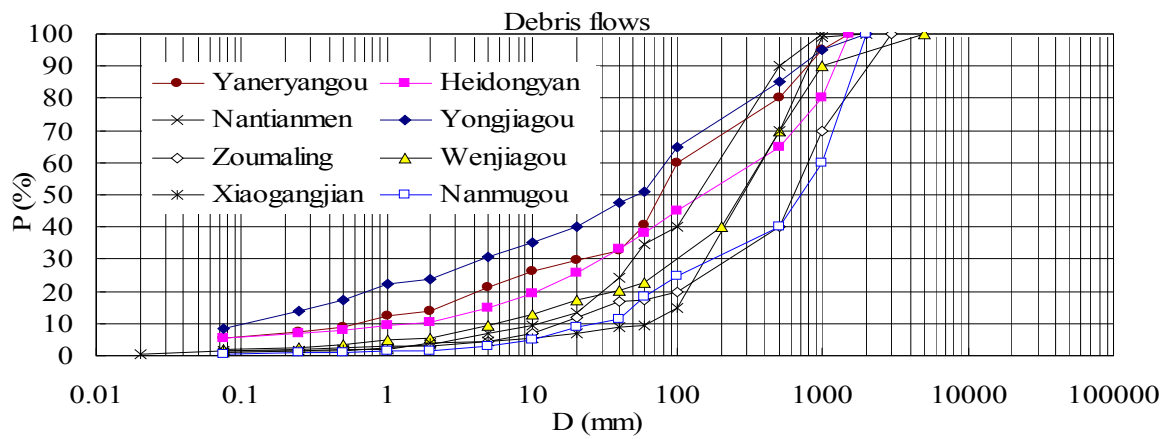

(b)

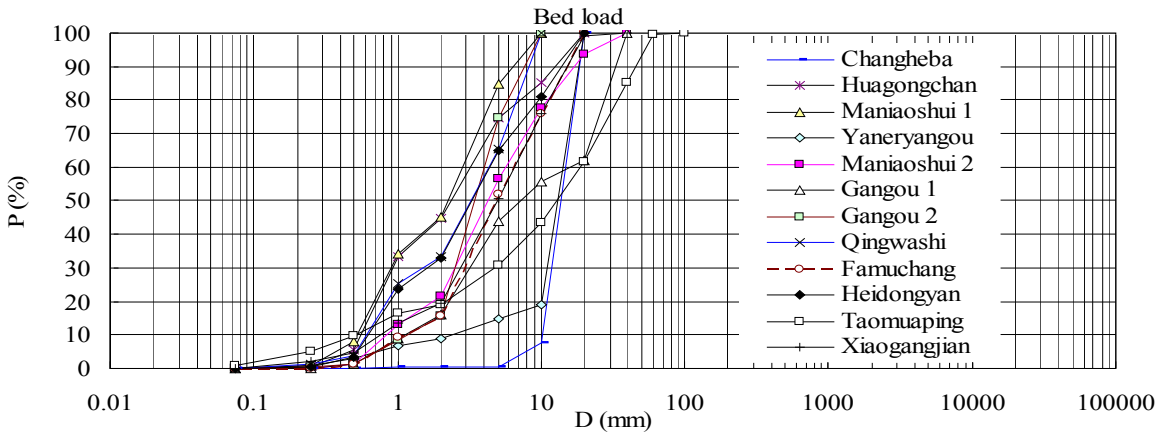

(c)

Figure 8. Grading of collapse landslides, debris flow and bed load.

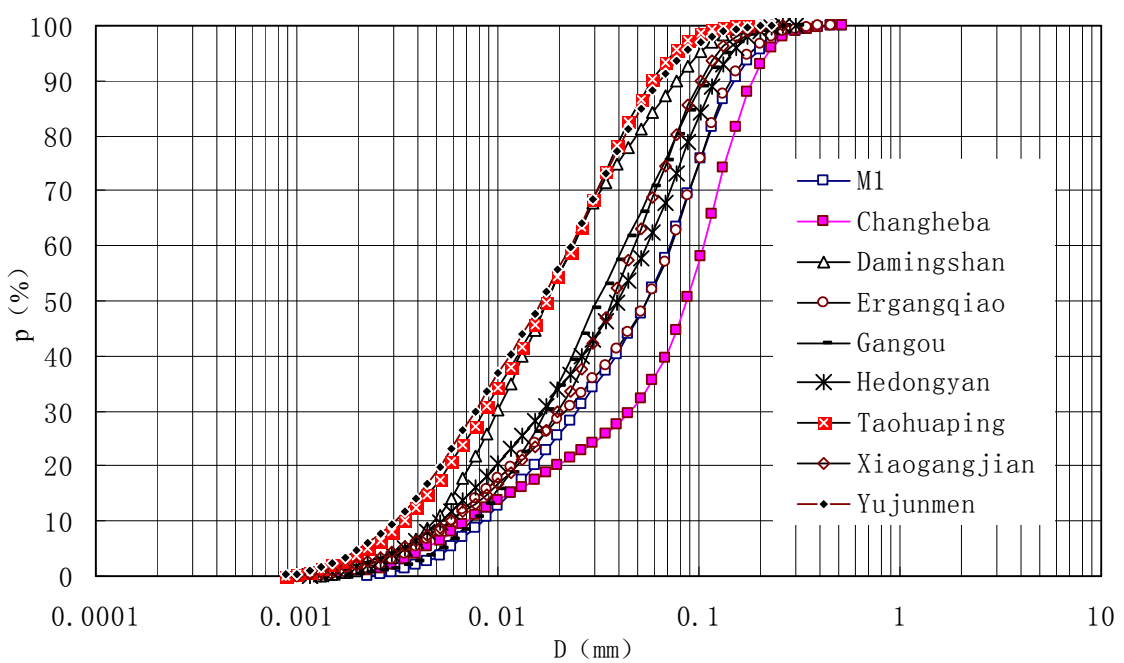

Figure 9. Grading of Sediment siltation in barrier lakes. 
mobilisation. The volume of material mobilised by the Wenchuan earthquake was 10 - 100 times greater than that mobilised by other forms of erosion. Since the collapse sediments are mainly composed of coarse particles, it is difficult to be transported to long distance with water. The coarsing riverbed can increase the riverbed resistance, reduce the sediment transport capacity. only a very small fraction $(<0.1 \%)$ of the sediment mobilised by earthquake erosion was transported over a long distance and reached the large rivers. Therefore, earthquake erosion has little effect on sediment transport and fluvial processes in large rivers.

\section{ACKNOWLEDGEMENTS}

The study reported in this contribution was supported by National Technology Support Project (2012BAK10B03) and the Ministry of Science and Technology of China (2008CB425803).

\section{REFERENCES}

[1] Dai, F.C., Xu, C., Yao, X., Xu, L., Tu, X.B. and Gong, Q.M. (2011) Spatial distribution of landslides triggered by the 2008 Ms 8.0 Wenchuan earthquake, China. Journal of Asian Earth Sciences, 40, 883-895. doi:10.1016/j.jseaes.2010.04.010

[2] Xie, H., Wang, S. and Kong, J. (2008) Distribution and characteristics of mountain hazards induced by the earthquake of May 12 in Wenchuan, China. Journal of Mountain Science, 26, 501-509.

[3] Chen, X.Q., Li, Z., Cui, P. and Liu, X.C. (2009) Estima- tion of soil erosion caused by the 5.12 Wenchuan Earthquake. Journal of Mountain Science, 27, 501-509.

[4] Wang, Z.Y., Cui, P. and Wang, R.Y. (2009) Mass movements triggered by the Wenchuan earthquake and management strategies of quake lakes. International Journal of River Basin Management, 7, 1-12.

[5] Cao, S.Y. Liu, X.N., Huang, E. and Yang, K.J. (2009) Advances in studies of river sediment and fluvial processes of the upper-Yangtze river in earthquake background. Journal of Sichuan University (Engineering Science Edition), 41, 26-34.

[6] Cui, P., Zhu, Y.Y., Han, Y.S., Chen, X.Q. and Zhuang, J. Q. (2009). The 12 May Wenchuan earthquake-induced landslide lakes: Distribution and preliminary risk evaluation. Landslides, 6, 209-223. doi:10.1007/s10346-009-0160-9

[7] Tang, C., Zhu, J. and Liang, J. (2009) Emergency assessment of seismic landslide susceptibility: A case study in the 2008 Wenchuan earthquake area. Earthquake Engineering and Engineering Vibration, 8, 207-217. doi:10.1007/s11803-009-9025-4

[8] Ying, W.H. and Wang, Y.L. (1999) Preliminary study on the change of water environment in Mianyuan River. Sichuan Environment, 18, 44-48.

[9] Chen, Z.J., Liu, S.Q. and Yang, D.G. (2000) Soil and water loss and its controlling countermeasures in the upper reaches of the Yangtze River. Journal of Soil Water Conservation, 14, 1-6.

[10] Tang, C., Zhu, J. and Qia, X. (2011) Landslide hazard assessment of the 2008 Wenchuan earthquake: A case study in Beichuan area. Canadian Geotechnical Journal, 48, 128145. doi:10.1139/T10-059 